\title{
Personality Profile Differences Between Prisoners and Non-Prisoners Using the Personality Inventory for DSM-5 (PID-5)
}

\author{
Widhi Adhiatma and Magdalena S. Halim \\ Faculty of Psychology \\ Atma Jaya Catholic University of Indonesia
}

\begin{abstract}
Prison provides correctional function for prisoners. There are some factors needed to be considered to enable the correctional process work optimally, one of them is the personality of prisoners. We need to consider this because there are different kinds of prisoners with different criminal backgrounds. This study aimed to identify the personality profiles of prisoners, including violent offenders, non-violent offenders and drug offenders, using the Indonesian version of Personality Inventory for DSM-5 (PID-5). We compared the personality profiles of the prisoners' groups with the non-prisoner's group in order to have more accurate personality profiles. The samples consisted of groups of violent offenders $(n=96$, mean age $=27.99$ years old), non-violent offenders ( $n=79$, mean age $=35.55$ years old $)$, drug offenders $(n=180$, mean age $=32.90$ years old $)$, and non-prisoners $(n=245$, mean age $=23.31$ years old $)$. Analyses using a series of One-Way ANOVA at the level of domains and facets of personality showed differences in the personality profiles of the three groups of prisoners and non-prisoner. In comparison to the non-prisoner group, the drug offender group was found having the largest number of differences in the personality profiles, whilst the non-violent offender group had the least number of personality profile differences.
\end{abstract}

\section{Keywords: personality, PID-5, prisoners}

Lembaga Pemasyarakatan (Lapas) memiliki fungsi pembinaan bagi para Warga Binaan Pemasyarakatan (WBP). Dalam melakukan pembinaan, perlu beberapa hal yang harus menjadi perhatian agar pembinaan dapat berjalan dengan optimal, salah satunya adalah aspek kepribadian dari para WBP. Hal ini mengingat dalam suatu Lapas terdapat berbagai macam WBP dengan latar belakang kejahatan yang berbeda-beda. Penelitian ini hendak mengetahui profil kepribadian WBP yang mencakup WBP Agresi, Non-Agresi, dan Narkotika berdasarkan Personality Inventory for DSM-5 (PID-5) versi Bahasa Indonesia. Peneliti membandingkan profil kepribadian ketiga kelompok WBP tersebut dengan kelompok Non-WBP untuk mendapatkan profil kepribadian secara lebih akurat. Sampel dari penelitian terdiri atas kelompok WBP Agresi ( $n=96$, rata-rata usia 27.99 tahun), WBP Non-Agresi $(n=79$, rata-rata usia 35.55 tahun), WBP Narkotika ( $n=180$, rata-rata usia 32.90 tahun), dan Non-WBP $(n=245$, rata-rata usia 23.31 tahun). Analisis menggunakan One-Way ANOVA pada tingkat domain dan facet menunjukkan adanya perbedaan profil kepribadian antara ketiga kelompok WBP dengan kelompok Non-WBP. Saat dibandingkan dengan kelompok Non-WBP, perbedaan paling banyak terdapat pada kelompok WBP Narkotika, sedangkan perbedaan paling sedikit terdapat pada kelompok WBP Non-Agresi.

Kata kunci: kepribadian, PID-5, Warga Binaan Pemasyarakatan

Direktorat Jenderal Pemasyarakatan (2016) reported as of January 2016, in the majority of prisons across 33 provinces in Indonesia, the number of prisoners exceeded the prisons' capacity. Only prisons in six provinces of Indonesia have adequate capacities

Correspondence concerning this article should be addressed to Widhi Adhiatma, Atma Jaya Catholic University of Indonesia, Jl. Jenderal Sudirman 51, Jakarta 12930. Email: widhi.adhiatma@gmail.com.
(Direktorat Jenderal Pemasyarakatan, 2016). Prisons have the function of correction for their prisoners, and this is in line with the changes in the Indonesian prison system in 1964 incorporating the correctional function in the system (Kusumowardhani \& Probowati, 2015). Changing in the prison system provides some challenges to the correctional institutions to reform prisoners' behavior. The correctional function is expected to mi- 
nimize the possibility that the prisoners repeat their crime (recidivism). Thus, the corrections or reformations should be done optimally.

According to Kusumowardhani and Probowati (2015), during the correctional process, it is important to consider the individual factor of prisoners, as prisoners who received the same punishment could have different psychological conditions. Willmot (in Towl, 2003) asserts that the individual factor of prisoners, including their behavior and thinking process, affects prisoner's behavior. For example, prisoners have tendencies to behave impulsively and aggressively, to have difficulties in understanding other people' points of view, and to have weaknesses in problem solving. Thus, the personality structure of prisoners affects their behavior, either when they commit a crime, while they are in prison or when they have finished their sentences.

According to Arif Nurcahyo (2015) who is the senior assessor of Human Resources Development of the Indonesian police department, criminal behavior is the result of various factors existing in society. The factors range from macro to micro aspects of human's life; that is, the personality of criminals. Based on his experience with criminal investigation process, he found that a criminal tended to have a certain type of personality. The personality of each criminal usually determined the pattern of crime committed. For example, criminals with introverted personality tended to be more expressive in committing crimes. These criminals usually committed murder and mutilation (Nurcahyo, personal communication, August $29^{\text {th }}, 2015$ ).

Research by Samuels, Bienvenu, Cullen, Costa, Eaton, and Nestadt (2004) used trait approach developed by McCrae and Costa to identify traits contributing to criminal acts. The result indicated the relationships between criminals' history of detention and some facets of personality measured by the NEO PIR. Participants admitted to detention obtained high scores in angry hostility, impulsiveness, and excitement seeking and low scores in intrust, straightforwardness, compliance, modesty, dutifulness, and deliberation. This study shows that personality is one of the important factors in predicting criminals' behavior apart from other factors.

Overall, a comprehensive assessment process is important to be conducted (Nathan, Cramond, Brown, McElin, \& Whittington, 2012) because each individual committing a crime has a unique personality. Unfortunately, according to Nurcahyo (personal communication, August 28, 2015), there has been a lack of systematic research on the relationship between perso- nality and crime in Indonesia. In this study, we aimed to compare the personality profiles of some group of prisoners and non-prisoners (individuals who have never been involved in legal cases). The comparisons of personality profiles could be used as a consideration by correctional institutions to conduct rehabilitation for prisoners, in particular to design correctional programs suitable to prisoners' personality. The prisoners were divided into three groups based on the category of criminals suggested in the criminal code act ("Kitab undang", n.d.), shown in Table 1.

When comparing the personality profiles, we adopted a dimensional approach from the DSM-5 pertained to pathological personality in order to have a comprehensive description of prisoners' personality. The model of personality disorder in the DSM-5 can identify pathological personality up to trait level. Along with high prevalence of pathological personality in forensic psychology, this model is useful as it can identify a variety of personality disorders among prisoners (American Psychiatric Association, 2013; Hemphill \& Hart, 2003; Hopwood \& Sellbom, 2013).

To facilitate the measurement of pathological traits, the member of Personality and Personality Disorders Work Group in the DSM-5 together with other consultants developed a measure named Personality Inventory for DSM-5 (PID-5), which was developed from the trait theory (Watson, Stasik, Ro, \& Clark, 2013). The PID-5 consists of 220 items in the form of self-report. The PID-5 has been adapted to Indonesian. The Indonesian version of PID-5 has been tested for validity and reliability and the results showed that the measure was ready to use in the Indonesian context (Adhiatma, Pinaima, Siregar, Nova, Kencana, Halim,

Table 1

The Types of Crimes Committed by Prisoners

\begin{tabular}{lc}
\multicolumn{1}{c}{ Type of Crime } & Group \\
\hline Crime against life & \\
Crime against security (physical & \\
assault) & Violent \\
Crime against property using & offenders
\end{tabular}

violence

Crime against property

Crime against morality

Crime against personal liberty

Crime related to fraud,

embezzlement, and corruption

violent

offenders

Crime related to counterfeiting

Crime related to drug

Drug

offenders 
\& Riyanti, 2014). In this study, it was expected that the prisoner groups would have higher scores on domains and facets of the PID-5 than the non-prisoner group.

\section{Method}

\section{Participants}

Participants in this research were classified into two groups: the prisoner and non-prisoner group, where the prisoner group was divided into three groups: violent offenders $(n=96$; males $=96$, females $=0)$, non-violent offenders $(n=79$; males $=77$, females $=2)$ and drug offenders $(n=180$; males $=159$, females $=$ 21). The participants from the prisoner group came from Lapas Kelas I Cipinang, Lapas Kelas II A Salemba, Lapas Narkotika Kelas II A Cipinang, Rutan Kelas I Cipinang, and Rutan Kelas II A Jakarta Timur. All prisoners have been convicted. Meanwhile, the non-prisoner participants were college students and employees $(n=245$, males $=88$, females $=157)$. Because of difficulties in accessing personal information, we used convenience sampling to obtain participants (Howitt \& Cramer, 2011). All participants had educational qualifications at least junior high school and aged 18 years old and above. These characteristics were similar to the eligibility criteria used in the study of PID-5 development by Krueger, Derringer, Markon, Watson, and Skodol (2012). The group of violent offenders, non-violent offenders, drug offenders, and non-prisoners had an average age of 27.99 years $(S D=9.96), 35.55$ years $(S D=11.90)$, 32.90 years, and 23.31 years $(S D=6.62)$, respectively. There were age differences among the four groups, $F(1,591)=46.13, p<.05$. However, the effect of age on personality profile was not found (Adhiatma, Pinaima, Siregar, Nova, \& Kencana, 2013).

\section{Procedures}

Data of prisoners were collected by administrating the test in group. We were assisted by research assistants when administrating the test. Meanwhile, the test for non-prisoners was administered both in group and individually. We supervised participants when they took the test either in group or individually to ensure that the methods of administration did not influence data collected. Before completing the PID-5 questionnaire, all participants had agreed to participate in this study by completing informed consent forms.

\section{Measures}

The measure used in this study was the Indonesian version of PID-5. The Indonesian version of PID-5 has been adapted and ready to be used. The values of Cronbach's Alpha for the PID-5 ranged from .63 to .82 , whereas the internal consistencies of this measure were at the range of $.47-.72$ (Adhiatma, Pinaima, Siregar, Nova, \& Kencana, 2013). The PID-5 measured five domains of pathological personality.

Negative Affectivity domain measures the tendency to have an intense experience with various negative emotions. This domain consists of eight facets: Emotional lability, Anxiousness, Separation Insecurity, Perseveration, Hostility, Depressivity, Suspiciousness, and Submissiveness. Antagonism domain measures the tendency to show eccentric behaviour because the person would like to form an impression of opposing others. This domain consists of five facets: Manipulativeness, Deceitfulness, Grandiosity, Attention Seeking, and Callousness. Detachment domain measures the tendency to avoid socio-emotional experiences. This domain consists of four facets: Withdrawal, Intimacy Avoidance, Anhedonia, and Restricted Affectivity.

Disinhibition domain measures the tendency to obtain immediate satisfaction or gratification. This domain consists of five facets: Irresponsibility, Impulsivity, Rigid Perfectionism, Risk Taking, and Distractibility. Psychoticism domain measures the tendency to show various unusual behaviour and thought which were not relevant to culture. This domain consists of three facets: Unusual beliefs and experiences, Eccentricity, dan Perceptual dysregulation. The PID-5 contains 220 statements with four optional answers ranging from "Very false or often false" to "Very true of often true". Participants were asked to match each statement to his or her condition by choosing one of the four optional answers. The answer was scored between 0 to 3 .

\section{Statistical Analysis}

The statistical analysis performed in this study was One-Way ANOVA. The analysis was used to determine whether there were significant differences on the personality profiles between the prisoner groups and non-prisoner group. To determine which group had significant differences, a series of Post Hoc Tests using Scheffe Test was performed (Gravetter \& Wallnau, 2013). The alpha level was set to 5\%. All analyses were conducted in domain and facet level. 
Before using one-way ANOVAs, we conducted a normality test for each data set, in particular we tested the significance of skewness and kurtosis values (Corder \& Foreman, 2009).

\section{Results}

For Negative Affectivity, the result showed that there was a significant difference between the four groups assessed, $F(3,596)=9.57, p<.05$. The Post Hoc analyses using Scheffe showed that violent $(M=$ $1.45, S D=0.05)$ and drug offenders $(M=1.48, S D=$ $0.04)$ had higher average scores than non-violent offenders $(M=1.20, S D=0.06)$ and non-prisoners $(M=1.28, S D=0.33)$.

The analysis of the Antagonism domain revealed a significant difference between the four groups assessed, $F(3,596)=10, p<.05$. The Post Hoc analyses using Scheffe showed that violent $(M=1.35, S D=0.06)$ and drug offenders $(M=1.38, S D=0.04)$ had higher average scores than non-violent prisoners $(M=1.10, S D=$ $0.06)$ and non-prisoners $(M=1.17, S D=0.03)$.

Data analysis on Detachment showed that there was a significant difference between the four groups assessed, $F(3,596)=32.58, p<.05$. The Post Hoc analyses using Scheffe showed that violent $(M=1.27$, $S D=0.04)$, non-violent $(M=1.21, S D=0.05)$ and drug offenders $(M=1.30, S D=0.03)$ had higher average scores than non-prisoners $(M=0.96, S D=0.02)$.

For Disinhibition, the result showed that there was a significant difference between the four groups assessed, $F(3,596)=13.52, p<.05$. The Post Hoc analyses using Scheffe showed that violent $(M=1.26, S D=$ $0.05)$ and drug offenders $(M=1.31, S D=0.03)$ had higher average scores than non-violent offenders $(M=$ $1.08, S D=0.05)$ and non-prisoners $(M=1.05, S D=$ $0.03)$.

The analysis of the Psychoticism domain showed that there was a significant difference between the four groups assessed, $F(3,596)=10, p<.05$. The Post Hoc analyses using Scheffe showed that violent $(M=1.11$, $S D=0.05)$, non-violent $(M=0.99, S D=0.06)$ and drug offenders $(M=1.15, S D=0.04)$ had higher average scores than non-prisoners $(M=0.84, S D=0.03)$.

Data analyses in the facets levels indicated that only one facet that did not have a significant difference, which was Manipulativeness $(p=.20)$. Meanwhile, the other 24 facets had significant differences between the four groups assessed. In the analyses conducted at the facet level, we compared the scores of the three groups of prisoners and non-prisoner group. When comparing the scores of prisoner and non-prisoner groups, the group of violent offenders had the highest scores in Hostility, Depressivity, Suspiciousness, Callousness, Withdrawal, Intimacy Avoidance, Anhedonia, Restricted Affectivity, Irresponsibility, Impulsivity, Unusual Beliefs and Experiences, and Perceptual Dysregulation.

In comparison to the non-prisoner group, nonviolent offenders had higher average scores in Depressivity, Suspiciousness, Deceitfulness (they were higher than the average scores of the group of violent and drug offenders), Callousness (they were considerably higher compared to the average scores of groups of violent and drug offenders), Withdrawal, Intimacy Avoidance, Anhedonia, Restricted Affectivity, Unusual Beliefs and Experiences, and Perceptual Dysregulation.

In comparison to the non-prisoner group, the group of drug offenders had higher scores in Anxiousness, Separation Insecurity, Perseveration, Hostility, Depressivity, Suspiciousness, Deceitfulness, Grandiosity, Attention Seeking, Callousness, Withdrawal, Intimacy Avoidance, Anhedonia, Restricted Affectivity, Irresponsibility, Impulsivity, Rigid Perfectionism, Distractibility, Unusual Beliefs and Experiences, dan Perceptual Dysregulation.

In conclusion, the group of drug offenders had the largest number of significant differences on the facets (20 facets), whereas the group of non-violent offenders had the lowest number of significant differences on the facets (10 facets). Furthermore, the group of nonviolent offenders had lower scores than the group of non-prisoners in Anxiousness, Hostility, Submissiveness (indicating a significant difference), Risk Taking (indicating a significant difference), and Eccentricity. Finally, on the submissiveness facet, all prisoner groups had lower scores than the non-prisoner group (see Appendix A).

\section{Discussion}

Among the three groups of prisoners tested, there were differences on the personality profiles between the prisoner and non-prisoner group in general. For the group of violent offenders, the significant differences were found in five domains of PID-5. The findings were consistent with Syukmawati's (2014) study focusing on the relationships between the five Big-5 domains and students' aggressivity. The results showed that the five Big-5 domains were significant predictors of students' aggressivity. Among the five Big5 domains, only Neuroticism domain (pertained to 
Negative Affectivity) was a negative predictor, while the other four domains were positive predictors.

In addition to have trait hostility, the group of violent offenders had a tendency to withdraw and have a lack of self-control (pertained to Detachment and Disinhibition domain). In this case, there were six facets with high average scores related to these two domains; that was, Withdrawal, Intimacy Avoidance, Anhedonia, Restricted Affectivity, Irresponsibility, and Impulsivity. From those trait combinations, the group of violent offenders had immature personalities characterized by limited interpersonal abilities and difficulties in managing impulses. The findings are in line with Levi's research (2004) focusing on violent criminals. This study shows that criminals tend to be free from other people's influences and need an immediate gratification (related to Detachment and Disinhibition domain), and have difficulties in paying attention to particular tasks (related to Detachment domain). With these personality traits, it is understandable that the individuals tend to break the law (Gauthier, Furr, Mathias, Marsh-Richard, \& Dougherty, 2009; Levi, 2004).

Meanwhile, drug offenders had similar personality profiles as those of violent offenders because significant differences were found in the five PID-5 domains with the non-prisoner group. In the facet level, the group of drug offenders had 20 significantly different facets when compared to the non-prisoner group. Apart from having the largest number of facets with high scores, the group of drug offenders had anxiety trait. In the Negative Affectivity domain, the group of drug offenders had the largest number of facets than the non-prisoner group, including Anxiousness, Separation Insecurity, Perseveration, Hostility, Depressivity, and Suspiciousness. This study confirms Ruiz's, Pincus', dan Schinka's (2008) finding showing that drug offenders obtained a relatively high score on Neuroticism (related to Negative Affectivity). Anxiety trait seems to be the unique characteristic of drug offenders in comparison to the other two groups of prisoners.

Furthermore, the group of drug offenders had a higher score in the Disinhibition domain in comparison to the non-prisoner group. A study by Ruiz, Pincus, and Schinka (2008) using the Big-5 test found that drug offenders had lower scores in Conscientiousness and Agreeableness. According to Markon, Krueger, and Watson (in Ruiz, Pincus, \& Schinka, 2008), low levels of Conscientiousness and Agree-ableness could develop into Disinhibition that is mostly apparent in externalizing disorder. The Disinhibition factor seems to enforce someone to perform risky behavior. In this case, inability to control impulses has made individuals extremely vulnerable to abuse substances as a form of risk-taking behaviour. Because of a lack of self-control and the influence of drug, individuals have difficulties in managing their impulses and dealing with substance abuse.

Among the three prisoner groups, the group of nonviolent offenders had the most similar traits as the non-prisoner group. There were only two different domains between both groups; that was, Detachment and Psychoticism. Additionally, in comparison to the other two prisoner groups, the group of non-violent offenders had the least number of facets having significantly higher scores than the non-prisoner group. We link this finding with cases that occurred recently in Indonesia, such as sexual harassment and corruption (both cases are included as the crime performed by the group of non-violent offenders). Sexual harassment to underage children has recently happened and the culprit is usually the victim's relatives. In order to approach the victim, the culprit usually does not perform externalizing behavior (e.g., showing hostility or rudeness). This is consistent with the previous research showing that sexual offenders did not have personality characteristics of Antisocial, Narcissistic, or Histrionic (Ahlmeyer, Kleinsasser, Stoner, \& Retzlaff, 2003).

Meanwhile, in corruption cases, the perpetrators of corruption are usually people who are employed or at middle to high social economic status, such as government officers, politicians, and entrepreneurs. The finding is different from that in the previous research where the perpetrators of economic crimes are described to be extrovert, disagreeable, and neurotic (Alalehto, as cited in Elliot, 2010). This might be influenced by culture differences in western and Indonesian culture. However, it should be noted that relatively small sample size could contribute to the differences.

Although the group of non-violent offenders has the most similar personality as the non-prisoner group, the non-violent offenders are considered as the 'coldest' group among the groups of prisoners. This can be seen from lower scores in the Emotional Lability, Anxiousness, Hostility, and Eccentricity facet in comparison to the non-prisoner group. Furthermore, in Deceitfulness and Callousness facet, the group of non-violent offenders had higher average scores than the other two groups. Thus, this group is considered as 'heartless' and extremely good in deceiving others.

Meanwhile, the non-prisoner group had lower scores in the five PID-5 domains compared to all pri- 
soner groups, except the group of non-violent offenders. Similarly in the facet level, the non-prisoner group had generally lower scores than the prisoner groups on all facets, except on Submissiveness. In this facet, the average score of the non-prisoner group were higher than all prisoner groups, particularly the group of nonviolent offenders. This indicates that individuals who are not related to law cases have more ability to adapt to their social environment. When they have impulses or desires to violate the rules, individuals that are not related to law cases have more ability to manage these and therefore, they do not violate the rules.

The group of prisoners' scores on Submissiveness are in line with the result of a study by Samuels et. al. (2004) who used NEO PI-R to identify prisoners' profiles. The prisoners were found to have a low score on Compliance facet. Based on their definitions, Submissiveness and Compliance have similarities although both facets are from different domains. The previous study of the Indonesian version of PID-5 indicates that Submissiveness appears as a separate factor (Adhiatma et al, 2014). The facet explains an individual's tendency to adapt his or her behavior to other people's condition, despite that this is not in line with his or her needs and desires. As a standalone facet, Submissiveness contributes greatly to the personality profile, including the profile of prisoners. Additionally, Submissiveness explains the dynamics of a person in committing crime, which is related to inability to manage his or her impulses and desires according to the demands from environment or social norms. This indicates the characteristics of antisocial personality (Millon, Grossman, Millon, Meagher, \& Ramnath, 2004). Thus, the antisocial personality of Indonesian criminals is more directed towards their inability to adapt to the environmental demands rather than showing an antagonistic attitude.

\section{Limitations}

This study has several limitations. Firstly, this study includes only a limited number of female participants, and therefore, it is difficult to generalize the results to female prisoners. Secondly, there were different test conditions between the prisoner and non-prisoner group. The room used for testing the non-prisoner group was more comfortable than that for the prisoner groups. For example, during test, the non-prisoner participants sat on the chairs in a room with air conditioning. The condition was different from the prisoner groups as data collection was conducted at prisons. The prisoner groups completed the PID- 5 by sitting on the floor in a room without air conditioning.

\section{Conclusions and Recommendations}

Based on the findings in this study, there were differences in the personality profiles between the non-prisoner group and the prisoner groups including groups of violent offenders, non-violent offenders, and drug offenders. The largest number of significant differrences was found between the group of drug offenders and the non-prisoner group, while the group of non-violent offenders had the least number of significant differences with the non-prisoner group. The three groups of prisoners had similarities with respect to the low levels of Submissiveness when compared to the non-prisoner group.

The results of this study are expected to provide benefits to the correctional institutions particularly with respect to psychological correction and rehabilitation for prisoners. The correctional institutions are recommended to provide correctional and rehabilitation programs in accordance to the personality characteristics of prisoner groups. For example, the correctional program for the group of non-violent offenders should aim to develop an empathy towards other people, whereas the program for the group of violent offenders should be designed to assist the prisoners to manage their impulses.

It is suggested that future studies can identify the personality profile of female prisoners, as in the process of developing the PID-5, a recent study revealed differences in the personality profiles of male and female participants (Adhiatma et al, 2013). Additionally, we suggest that future researchers employ a regression analysis to identify which personality traits that can be used to predict if a person will commit a crime or not. Thus, the correctional institutions would receive more benefits from this type of study facilitating the process of correction and rehabilitation of prisoners.

\section{References}

Adhiatma, W., Pinaima, R., Siregar, L. B., Nova, P., \& Kencana, K. (2013). Manual adaptasi alat ukur Personality Inventory for DSM-5. Jakarta: Penulis. Adhiatma, W., Pinaima, R., Siregar, L. B., Nova, P., Kencana, K., Halim, M. S., \& Riyanti, B. P. D. (2014). Exploratory factor analysis for Indonesian version of PID-5. Anima, 29(4), 199-206.

Ahlmeyer, S., Kleinsasser, D., Stoner, J. \& Retzlaff, P. 
(2003). Psychopathology of incarcerated sex offenders. Journal of Personality Disorders, 17(4), 306-318.

American Psychiatric Association. (2013). Diagnostic and statistical manual of mental disorder. $\left(5^{\text {th }} \mathrm{ed}\right.$.). Washington DC: Authors.

Corder, G. W. \& Foreman, D. I. (2009). Nonparametric statistics for non-statisticians: A step-by-step approach. New Jersey: John Wiley \& Sons, Inc.

Direktorat Jenderal Pemasyarakatan. (2016). Data terakhir jumlah penghuni perkanwil. Retrieved from http://smslap.ditjenpas.go.id/public/grl/current /monthly/year/2015/month/2

Elliott, R. T. (2010). Examining the relationship between personality characteristics and unethical behaviors resulting in economic crime. Ethical Human Psychology and Psychiatry, 12(3), 269-276.

Gauthier, K. J., Furr, R. M., Mathias, C. W., MarshRichard, D. M., \& Dougherty, D. M. (2009). Differentiating impulsive and premeditated aggression: Self and informant perspectives among adolescents with personality pathology. Journal of Personality Disorders, 23(1), 76-84.

Gravetter, F. J. \& Wallnau, L. B. (2013). Statistics for the behavioral sciences (9th ed). Belmont: Thomson Wadsworth.

Hemphill, J. F. \& Hart, S. D. (2003). Forensic and clinical issues in the assessment of psychopathy. Dalam Goldstein, A. M. \& Weiner, I. B. (Ed.). Handbook of psychology: Volume II: Forensic psychology. (pp. 87-107). New Jersey: John Wiley \& Sons, Inc.

Hopwood, C. J. \& Sellbom, M. (2013). Implication of DSM-5 personality traits for forensic psychology. Psychological Injury and Law, 6, 314-323.

Howitt, D. \& Cramer, D. (2011). Introduction to research methods in psychology. (3rd ed). Essex: Pearson Education Limited.

Kitab undang-undang hukum pidana (wetboek van strafrecht). (n.d.). Retrieved from http://hukum. unsrat.ac.id/uu/kuhpidana.htm

Krueger, R. F., Derringer, J., Markon, K. E., Watson, D., Skodol, A. E. (2012). Initial construction of a maladaptive personality trait model and inventory for DSM-5. Psychological Medicine, 42, 1879-1890.
Kusumowardhani, R. \& Probowati, Y. (2015, 27 April). Psikologi dalam lembaga pemasyarakatan. Retrieved from http://himpsi.or.id/index.php/organi sasi/himpsi-wilayah/43-semua-kategori/non-menu/ pengumuman/55-hari-bhakti-lapas-2015

Levi, M. D. (2004). Aggression subtypes: The role of neuropsychological functioning and personality (Unpublished doctoral dissertation). York University, Canada.

Millon, T., Grossman, S., Millon, C., Meagher, S., \& Ramnath, R. (2004). Personality disorders in modern life. (2nd ed). New Jersey: John Wiley \& Sons, Inc.

Nathan, R., Cramond, L., Brown, A., McEllin, B., \& Whittington, R. (2012). Approaches to personality disordered offenders: Experiential and empirical lessons from the forensic personality disorder assessment and liaison service. The British Journal of Forensic Practice, 14(4), 261-291.

Nurcahyo, A. (2015, Agustus 28). Catatan psikologi: (Profile) kejahatan. Presented at Scientific Conference: Personality Excellence: Tackling Challenges in Contemporary Society, Jakarta.

Ruiz, M. A., Pincus, A. L., \& Schinka, J. A. (2008). Externalizing pathology and the Five-Factor Model: A meta-analysis of personality traits associated with antisocial personality disorder, substance use disorder, and their co-occurence. Journal of Personality Disorders, 22(4), 365-388.

Samuels, J., Bienvenu, O. J., Cullen, B., Costa, P. T., Eaton, W. W., \& Nestadt, G. (2004). Personality dimensions and criminal arrest. Comprehensive Psychiatry, 45(4), 275-280.

Syukmawati, Y. (2014). Pengaruh Big Five Personality dan attachment style terhadap agresivitas. (Unpublished mini-thesis). Jakarta: Universitas Islam Negeri Syarif Hidayatullah.

Watson, D, Stasik, S. M., Ro, E., Clark, L. A. (2013). Integrating normal and pathological personality: Relating the DSM-5 trait-dimensional model to general traits of personality. Assessment, 20(3), 312-326.

Willmot, P. (2003). Applying the research on reducing recidivism to prison regimes. In Towl, G. (Ed.). Psychology in prisons. (pp. 35-51). Oxford: British Psychological Society and Blackwell Publishing Ltd. 


\section{Appendix}

Test Results with One-Way ANOVA and Post Hoc

\begin{tabular}{|c|c|c|c|c|c|c|c|}
\hline & & $\begin{array}{c}\text { Non- } \\
\text { prisoners }\end{array}$ & $\begin{array}{c}\text { Violent } \\
\text { offenders }\end{array}$ & $\begin{array}{c}\text { Non-violent } \\
\text { offenders }\end{array}$ & $\begin{array}{c}\text { Drug } \\
\text { offenders }\end{array}$ & $F$ & $p$-value \\
\hline \multirow{3}{*}{ Negative Affectivity } & $M$ & $\underline{1.28}$ & 1.45 & 1.20 & 1.48 & \multirow{3}{*}{9.567} & \multirow{4}{*}{$.00^{*}$} \\
\hline & $S D$ & 0.03 & 0.05 & 0.06 & 0.04 & & \\
\hline & Post Hoc & - & $.04 *$ & .73 & $.00 *$ & & \\
\hline \multirow{3}{*}{ Emotional Lability } & $M$ & $\underline{1.27}$ & 1.48 & 1.11 & 1.44 & \multirow{3}{*}{6.732} & \\
\hline & $S D$ & 0.04 & 0.07 & 0.08 & 0.05 & & \multirow[t]{3}{*}{$.00 *$} \\
\hline & Post Hoc & - & .08 & .33 & .08 & & \\
\hline \multirow{3}{*}{ Anxiousness } & $M$ & $\underline{1.51}$ & 1.54 & 1.50 & 1.73 & \multirow{3}{*}{5.939} & \\
\hline & $S D$ & 0.04 & 0.06 & 0.06 & 0.04 & & \multirow[t]{3}{*}{$.00 *$} \\
\hline & Post Hoc & - & .96 & 1.00 & $.00 *$ & & \\
\hline & $M$ & 1.02 & 1.20 & 1.11 & 1.24 & \multirow{4}{*}{5.191} & \\
\hline \multirow[t]{3}{*}{ Separation Insecurity } & $S D$ & 0.04 & 0.06 & 0.07 & 0.05 & & \multirow[t]{3}{*}{$.00 *$} \\
\hline & Post Hoc & - & .10 & .71 & $.00 *$ & & \\
\hline & M & 1.21 & 1.37 & 1.28 & 1.48 & & \\
\hline \multirow[t]{3}{*}{ Perseveration } & $S D$ & 0.03 & 0.06 & 0.06 & 0.04 & \multirow[t]{3}{*}{9.934} & \multirow[t]{3}{*}{$.00 *$} \\
\hline & Post Hoc & - & .08 & .74 & $.00 *$ & & \\
\hline & $M$ & $\underline{1.05}$ & 1.34 & 0.99 & 1.28 & & \\
\hline \multirow[t]{3}{*}{ Hostility } & $S D$ & 0.03 & 0.06 & 0.07 & 0.04 & \multirow[t]{3}{*}{11.239} & \multirow[t]{3}{*}{$.00^{*}$} \\
\hline & Post Hoc & - & $.00 *$ & .90 & $.00 *$ & & \\
\hline & $M$ & 0.70 & 1.19 & 0.99 & 1.14 & & \\
\hline \multirow[t]{3}{*}{ Depressivity } & $S D$ & 0.03 & 0.06 & 0.06 & 0.04 & \multirow[t]{3}{*}{36.674} & \multirow[t]{3}{*}{$.00 *$} \\
\hline & Post Hoc & - & $.00 *$ & $.00 *$ & $.00 *$ & & \\
\hline & $M$ & 1.20 & 1.45 & 1.42 & 1.55 & & \\
\hline \multirow[t]{3}{*}{ Suspiciousness } & $S D$ & 0.03 & 0.05 & 0.05 & 0.03 & 23.489 & $.00^{*}$ \\
\hline & Post Hoc & - & $.00 *$ & $.00 *$ & $.00^{*}$ & & \\
\hline & $M$ & $\underline{1.47}$ & 1.28 & 1.10 & 1.36 & & \\
\hline Submissiveness & $S D$ & 0.03 & 0.07 & 0.07 & 0.04 & 8.280 & $.00^{*}$ \\
\hline & Post Hoc & - & .07 & $.00 *$ & .36 & & \\
\hline & $M$ & $\underline{1.17}$ & 1.35 & 1.10 & 1.38 & & \\
\hline Antagonism & $S D$ & 0.03 & 0.06 & 0.06 & 0.04 & 10.000 & $.00^{*}$ \\
\hline & Post Hoc & - & $.03 *$ & .72 & $.00 *$ & & \\
\hline & $M$ & 1.01 & 1.07 & 1.16 & 1.09 & & \\
\hline Manipulativeness & $S D$ & 0.04 & 0.07 & 0.07 & 0.05 & 1.573 & .20 \\
\hline & Post Hoc & - & .83 & .26 & .48 & & \\
\hline & $M$ & 0.75 & 0.89 & 1.05 & 1.02 & & \\
\hline Deceitfulness & $S D$ & 0.03 & 0.05 & 0.07 & 0.04 & 11.197 & $.00^{*}$ \\
\hline & Post Hoc & - & .19 & $.00 *$ & $.00^{*}$ & & \\
\hline & $M$ & 1.14 & 1.23 & 1.31 & 1.36 & & \\
\hline Grandiosity & $S D$ & 0.03 & 0.07 & 0.07 & 0.04 & 5.381 & $.00 *$ \\
\hline & Post Hoc & - & .68 & .14 & $.00 *$ & & \\
\hline & $M$ & 1.37 & 1.47 & 1.42 & 1.57 & & \\
\hline Attention Seeking & $S D$ & 0.04 & 0.07 & 0.08 & 0.04 & 4.008 & $.01^{*}$ \\
\hline & Post Hoc & - & .57 & .94 & $.01 *$ & & \\
\hline & $M$ & 0.55 & 0.84 & 0.98 & 0.84 & & \\
\hline Callousness & $S D$ & 0.02 & 0.05 & 0.06 & 0.04 & 24.653 & $.00^{*}$ \\
\hline & Post Hoc & - & $.00 *$ & $.00 *$ & $.00^{*}$ & & \\
\hline
\end{tabular}




\begin{tabular}{|c|c|c|c|c|c|c|c|}
\hline & & $\begin{array}{c}\text { Non- } \\
\text { prisoners }\end{array}$ & $\begin{array}{c}\text { Violent } \\
\text { offenders }\end{array}$ & $\begin{array}{c}\text { Non-violent } \\
\text { offenders }\end{array}$ & $\begin{array}{c}\text { Drug } \\
\text { offenders }\end{array}$ & $F$ & $p$-value \\
\hline & $M$ & 0.96 & 1.27 & 1.21 & 1.30 & \multirow{4}{*}{32.576} & \multirow{4}{*}{$.00^{*}$} \\
\hline \multirow[t]{3}{*}{ Detachment } & $S D$ & 0.02 & 0.04 & 0.05 & 0.03 & & \\
\hline & Post Hoc & - & $.00 *$ & $.00 *$ & $.00 *$ & & \\
\hline & $M$ & 0.90 & 1.34 & 1.17 & 1.37 & & \\
\hline \multirow[t]{3}{*}{ Withdrawal } & $S D$ & 0.03 & 0.06 & 0.06 & 0.04 & \multirow[t]{3}{*}{33.817} & \multirow[t]{3}{*}{$.00 *$} \\
\hline & Post Hoc & - & $.00^{*}$ & $.00^{*}$ & $.00 *$ & & \\
\hline & $M$ & 0.73 & 0.99 & 1.01 & 0.93 & & \\
\hline \multirow[t]{3}{*}{ Intimacy Avoidance } & $S D$ & 0.03 & 0.06 & 0.06 & 0.04 & \multirow[t]{3}{*}{9.397} & \multirow[t]{3}{*}{$.00^{*}$} \\
\hline & Post Hoc & - & $.00 *$ & $.00 *$ & $.00 *$ & & \\
\hline & $M$ & 0.83 & 1.16 & 1.02 & 1.13 & & \\
\hline \multirow[t]{3}{*}{ Anhedonia } & $S D$ & 0.03 & 0.05 & 0.06 & 0.03 & \multirow[t]{3}{*}{19.600} & \multirow[t]{3}{*}{$.00 *$} \\
\hline & Post Hoc & - & $.00 *$ & $.02 *$ & $.00 *$ & & \\
\hline & $M$ & 1.25 & 1.48 & 1.45 & 1.60 & & \\
\hline \multirow{3}{*}{ Restricted Affectivity } & $S D$ & 0.03 & 0.06 & 0.06 & 0.03 & \multirow{3}{*}{18.934} & \multirow[t]{3}{*}{$.00^{*}$} \\
\hline & Post Hoc & - & $.00 *$ & $.02 *$ & $.00 *$ & & \\
\hline & $M$ & 1.05 & 1.26 & 1.08 & 1.31 & & \\
\hline \multirow[t]{3}{*}{ Disinhibition } & $S D$ & 0.03 & 0.05 & 0.05 & 0.03 & \multirow[t]{3}{*}{13.521} & \multirow[t]{3}{*}{$.00 *$} \\
\hline & Post Hoc & - & $.00 *$ & .95 & $.00 *$ & & \\
\hline & $M$ & 0.82 & 1.11 & 0.89 & 1.03 & & \\
\hline \multirow[t]{3}{*}{ Irresponsibility } & $S D$ & 0.03 & 0.06 & 0.07 & 0.04 & \multirow[t]{3}{*}{10.958} & \multirow[t]{3}{*}{$.00^{*}$} \\
\hline & Post Hoc & - & $.00^{*}$ & .70 & $.00 *$ & & \\
\hline & M & 1.12 & 1.40 & 1.13 & 1.40 & & \\
\hline \multirow[t]{3}{*}{ Impulsivity } & $S D$ & 0.04 & 0.07 & 0.08 & 0.04 & 10.609 & $.00 *$ \\
\hline & Post Hoc & - & $.00 *$ & 1.00 & $.00 *$ & & \\
\hline & $M$ & 1.48 & 1.52 & 1.53 & 1.69 & & \\
\hline Rigid Perfectionism & $S D$ & 0.03 & 0.06 & 0.06 & 0.03 & 5.584 & $.00 *$ \\
\hline & Post Hoc & - & .96 & .94 & $.00^{*}$ & & \\
\hline & $M$ & $\underline{1.43}$ & 1.45 & 1.27 & 1.48 & & \\
\hline Risk Taking & $S D$ & 0.02 & 0.05 & 0.04 & 0.03 & 5.090 & $.00 *$ \\
\hline & Post Hoc & - & .99 & $.02 *$ & .77 & & \\
\hline & $M$ & 1.21 & 1.25 & 1.23 & 1.49 & & \\
\hline Distractibility & $S D$ & 0.04 & 0.06 & 0.06 & 0.04 & 9.872 & $.00 *$ \\
\hline & Post Hoc & - & .95 & 1.00 & $.00 *$ & & \\
\hline & $M$ & 0.84 & 1.11 & 0.99 & 1.15 & & \\
\hline Psychoticism & $S D$ & 0.03 & 0.05 & 0.06 & 0.04 & 15.200 & $.00 *$ \\
\hline & Post Hoc & - & $.00 *$ & $.04 *$ & $.00 *$ & & \\
\hline Unusual Beliefs and & $M$ & 0.83 & 1.18 & 1.17 & 1.22 & & \\
\hline Experiences & $S D$ & 0.04 & 0.06 & 0.07 & 0.05 & 17.148 & $.00^{*}$ \\
\hline & Post Hoc & - & $.00 *$ & $.00 *$ & $.00 *$ & & \\
\hline & M & $\underline{0.95}$ & 1.03 & 0.83 & 1.06 & & \\
\hline Eccentricity & $S D$ & 0.04 & 0.06 & 0.06 & 0.04 & 3.268 & $.02 *$ \\
\hline & Post Hoc & - & .47 & .71 & .11 & & \\
\hline & $M$ & 0.74 & 1.11 & 0.99 & 1.19 & & \\
\hline Perceptual Dysregulation & $S D$ & 0.03 & 0.06 & 0.06 & 0.04 & 27.132 & $.00 *$ \\
\hline & Post Hoc & - & $.00 *$ & $.00 *$ & $.00 *$ & & \\
\hline
\end{tabular}

